\title{
DEIKSIS DALAM INTERAKSI VERBAL PADA MAHASISWA DI SURABAYA
}

\author{
Naji’atul Musfiro, Luluk Isani Kulup \\ Pendidikan Bahasa Indonesia, Fakultas Ilmu Sosial dan Humaniora, Universitas \\ PGRI Adi Buana Surabaya \\ Najiatulmusfiro03@gmail.com,luluk@unipasby.ac.id
}

\begin{abstract}
ABSTRAK
Penelitian ini pada dasarnya dari adanya keragaman bahasa dan menunjukkan beberapa deiksis dalam Interaksi Verbal pada Mahasiswa Surabaya. Deiksis dibagi menjadi tiga macam, yaitu deiksis orang, deiksis tempat, dan deiksis waktu. Hal tersebut tidak hanya terjadi pada orang-orang yang hidup dalam bahasa yang sama misalnya bahasa Jawa, tetapi juga terjadi pada mahasiswa yang kuliah di Surabaya. Penelitian ini merupakan jenis penelitian deskriptif kualitatif. Tujuan penelitian ini adalah mendeskripsikan penggunaan deiksis dalam interaksi verbal mahasiswa Surabaya. Sumber data dari penelitian ini adalah mahasiswa di Surabaya yang merupakan sumber data tertulis atau yang bisa disebut dengan sumber data dalam penelitian ini. Teknik yang digunakan dalam pengumpulan data dari teknik tap Sap kemudian dilanjutkan dengan teknik lanjutan berupa (mendengar, melihat, cakap) dan teknik mencatat tingkat lanjut. Berdasarkan hasil penelitian dan pembahasan, peneliti menyimpulkan bahwa terdapat tiga jenis deiksis yang muncul dalam 90 data yang dianalisis, yaitu deiksis persona yang terbagi menjadi tiga jenis, yaitu deiksis persona pertama, deiksis persona kedua, deiksis persona ketiga, deiksis waktu, dan deiksis tempat. Penggunaan deiksis yang paling banyak muncul dalam Percakapan Interaksi Verbal Mahasiswa Surabaya adalah deiksis persona.
\end{abstract}

Kata kunci: mahasiswa Surabaya, Prakmatika, Deiksis.

\section{PENDAHULUAN}

Bahasa merupakan sarana komunikasi paling utama yang digunakan oleh manusia, sehingga bahasa dapat digunakan oleh siapa saja, di mana saja, dan kapan saja. Pada saat menggunakan itu terjadi referen yang tidak tetap atau berubah-ubah. Referen ini bersifat pada benda atau orang yg diacu oleh kata atau untaian kata dalam kalimat atau konteks tertentu, Karena itu disebut dengan Deiksis.

Deiksis adalah kata atau ungkapan referen yang berubah-ubah, bergantung pada siapa yang menjadi pembicara. Menurut (Purwo, 1980:10) sebuah kata dikatakan bersifat Deiksis apabila referennya berpindah-pindah atau berganti-ganti, bergantung pada siapa yang menjadi si pembicara dan tergantung pada saat dan tempat dituturan kata itu. Dalam pragmatik, kajian deiksis dibagi menjadi lima, yaitu: deiksis orang, deiksis tempat, deiksis waktu, deiksis wacana, dan deiksis sosial. Hal tersebut tidak hanya terjadi pada orang-orang yang hidup di sekitar kita dalam satu bahasa, misalnya orang Jawa. Hal ini juga terjadi dalam mahasiswa surabaya yang sedang menuntut ilmu di Surabaya.

Surabaya adalah sebagai salah satu kota tujuan pendidikan, Surabaya juga menjadi tempat tinggal mahasiswa dari berbagai daerah dari seluruh Indonesia, bahkan di antara mereka juga membentuk wadah komunitas tersendiri. 
Dari paparan tersebut, penelitian ini bertujuan mendiskripsikan penggunaan deiksis alam interaksi verbal mahasiswa di Surabaya. Sebagai objek penelitian, Pragmatik adalah studi tentang makna yang disampaikan oleh penutur (atau penulis) dan ditafsirkan oleh pendengar (atau pembaca). Pragmatik sebagai berikut: Pragmatics is the study of those relations between language and context that are grammaticalized, or encoded in the structure of a language. ("Pragmatik adalah studi tentang hubungan antara bahasa dan konteks yang secara tata bahasa, atau dikodekan dalam struktur suatu bahasa") Levinson (1983:9). Definisi lain mengenai pragmatik diberikan oleh Nababan (dalam Sudaryat, 1987) menjelaskan bahwa pragmatik berkenaan dengan penggunaan bahasa secara efektif dan wajar untuk berkomunikasi dalam situasi tertentu.

Sebuah kata dikatakan bersifat deiksis apabila referennya berpindah-pindah atau berganti-ganti, tergantung pada siapa yang menjadi si pembicara dan tergantung pada saat dan tempat dituturkannya kata itu. Kata deiksis berasal dari kata Yunani deiktos, yang berarti 'hal penunjukkan secara langsung'. (Purwo, 1984:80).

Deiksis adalah bentuk bahasa yang berfungsi sebagai penunjuk hal atau fungsi tertentu di luar bahasa. Sesuatu yang diacu oleh deiksis disebut anteseden Sudaryat (2009:132). Dilihat dari anntesedennya deiksis dibedakan atas lima macam yakni deiksis persona, deiksis temporal, deiksis lokatif, deiksis wacana, dan deiksis sosial (Levinson dalam Sudaryat, 2009:132).

Fenomena deiksis merupakan cara paling jelas untuk menggambarkan hubungan antara bahasa dan konteks di dalam struktur bahasa itu sendiri. Upaya deiksis dapat berupa : (1) pronomina persona (orangan), nama diri, demonstrasitif, (2) kata (tense), (3) keaspekan (ciri gramatikal waktu/leksikal waktu). Djajasudarma (2012:55)

(Levinson, 1983:69) menyebutkan bahwa dalam Bahasa Inggris Deiksis dapat diklasifisikan menjadi tiga jenis, yaitu Deiksis Persona 'person deixis', deiksis ruang 'place deixis', dan deiksis waktu 'time deixis'. Adapun definisi yang diberikan untuk menjelaskan perbedaan masing-masing deiksis adalah sebagai berikut :

Person deixis concerns the encoding of the role of participants in the speech event in which the utterance in question is delivered. Place deixis concerns the encoding of spatial locations relative to the location of the participants in the speech event. Time deixis concerns the encoding of temporal points and spans relative to the time at which an utterance was spoken (or a written message inscribed).

("Deiksis persona berhubungan dengan pemahaman mengenai peserta pertuturan dalam situasi pertuturan di mana tuturan tersebut dibuat. Deiksis tempat berhubungan dengan pemahaman lokasi atau tempat yang dipergunakan peserta pertuturan dalam situasi pertuturan. Deiksis waktu berhubungan dengan pemahaman titik ataupun rentang waktu saat tuturan dibuat (atau pada saat pesan tertulis dibuat)").

Menurut Levinson (dalam Nadar 2013:55) Deiksis persona berhubungan dengan pemahaman mengenai peserta pertuturan dalam situasi pertuturan di mana tuturan tersebut dibuat. Penggunaan kata ganti orang pertama adalah referensi penutur untuk dirinya sendiri, orang kedua untuk menunjuk kepada satu atau lebih 
lawan tuturannya, sedangkan orang ketiga untuk menunjuk selain diri penutur maupun lawan tuturannya.

Deiksis persona menerapkan tiga pembagian dasar, yang dicontohkan dengan kata ganti orang pertama ("Saya"), orang kedua ("Kamu"), dan orang ketiga ("Dia lk", "dia pr", atau "dia barang/sesuatu"). Kesederhanaan bentuk-bentuk ini menyembunyikan kerumitan pemakaiannya. Dalam beberapa bahasa kategori deiksis penutur, kategori deiksis lawan tutur dan kategori deiksis lainnya diuraikan panjang lebar dengan tanda status sosial kekerabatan. (Yule, 2014:19)

Deiksis waktu adalah pemakaian bentuk proksimal 'sekarang' yang menunjukkan baik waktu yang berkenaan dengan saat penutur berbicara maupun saat suara penutur sedang didengar. (Yule, 2014:19)

Mengenai deiksis waktu Levinson (dalam Nadar 1983:73) menunjukkan keterkaitannya dengan kataa tense dan adverbia penanda waktu 'time adverbs'. Senada dengan itu, menurut Mey (dalam Nadar 1993:93), ungkapan-ungkapan deiksis waktu menunjuk pada suatu keadaan dengan sudut pandang tertentu.

Deiksis tempat yaitu hubungan antara orang dan bendanya ditunjukkan. Bahasa Inggris kontemporer hanya memakai dua kata keterangan 'di sini' dan 'di sana', tetapi dalam teks-teks lama dan dalam beberapa dialek, dapat ditemukan seperangkat ungkpan deiksis yang jauh lebih banyak. (Yule, 2014:19)

Place deixis concerns the encoding of spatial locations relative to the location of the participants in the speech event. ("Deiksis tempat berhubungan dengan pemahaman lokasi atau tempat yang dipergunakan peserta pertuturan dalam situasipertuturan"). Sudaryat (2009:134) menyatakan deiksis tempat digunakan untuk mengacu tempat berlangsungnya kejadian, baik tempat dekat (proksimal), agak jauh (semi-proksimal), maupun tempat jauh (distal). (Levinson, 1983:69)

Surabaya merupakan kota multi etnis yang kaya budaya. Mahasiswa Surabaya adalah mahasiswa yang belajar di perguruan tinggi dan memiliki variasi bahasa yang berbeda-beda. Perguruan tinggi yang ada di Surabaya, tidak saja mampu menampung mahasiswa yang berasal dari Kota Surabaya, namun juga mahasiswa yang berasal dari daerah-daerah lain di Indonesia. Mahasiswa Surabaya, mahasiswa yang terdiri dari berbagai macam suku bangsa dan budaya.

Mahasiswa Surabaya adalah mahasiswa yang memiliki variasi bahasa berbeda-beda dan mahasiswa yang terdiri dari berbagai macam suku bangsa dan budaya. Sebagai suatu paham yang bergerak untuk memahami dan menerima segenap perbedaan yang ada pada setiap individu manusia pada sebuah konsep komunitas dalam konteks kebangsaan dapat mengakui keberagaman, perbedaan, dan kemajemukan budaya, ras, agama, dan bahasa.

\section{METODE PENELITIAN}

Penelitian tentang penggunaan deiksis dalam interaksi verbal pada mahasiswa di surabaya menggunakan pendekatan kualitatif. Penelitian ini merupakan penelitian deskriptif yang bertujuan untuk mendeskripsikan penggunaan deiksis dalam interaksi verbal yang dilakukan dalam peristiwa tutur tersebut.

Penelitian kualitatif adalah penelitian yang bermaksud untuk memahami fenomena tentang apa yang dialami oleh subjek penelitian misalnya perilaku, persepsi, motivasi, tindakan, dll., secara holistik, dan dengan cara deskripsi dalam 
bentuk kata-kata dan bahasa, pada suatu konteks khusus yang alamiah dan dengan memanfaatkan berbagai metode alamiah. (Moleong, 2016:6).

Data penelitian kualitatif deskriptif berupa kata-kata yang berupa bentuk deiksis dalam percakapan Mahasiswa di Surabaya. Adapun data dalam penelitian ini adalah data yang berwujud kata dan kalimat menggunakan deiksis yang diucapkan oleh mahasiswa di Surabaya. Lebih tepatnya Mahasiswa yang kuliah di Surabaya yang berada di kafe dan di taman.

Lofland dan Lofland (1984:47) sumber data utama dalam penelitian kualitatif ialah kata-kata, dan tindakan, selebihnya adalah data tambahan seperti dokumen dan lain-lain. Pada penelitian ini sumber data yang digunakan adalah Mahasiswa Di Surabaya.

Teknik pengumpulan data berupa teknik Sadap, kemudian dilanjutkan dengan teknik lanjutan berupa (simak libat cakap) dan teknik lanjutan catat. Menurut Sudaryanto (dalam muhammad 1993:133) menyatakan bahwa untuk menyimak objek penelitian dilakukan dengan menyadap. Dengan kata lain, metode simak secara praktik dilakukan dengan menyadap. Untuk ketiga teknik tersebut di jelaskan sebagai berikut: (1) Teknik sadap disebut teknik dasar dalam metode simak, karena pada hakikatnya penyimak diwujudkan dengan penyadapan. Teknik ini digunakan untuk menyadap atau merekam dengan alat perekam suara tentang percakapan yang dilakukan oleh mahasiswa surabaya di sebuah kafe dan taman yang ada di Surabaya. (2) Teknik simak libat cakap, Teknik ini digunakan untuk menyimak percakapan mahasiswa surabaya yang sebelumnya sudah direkam menggunakan alat perekam suara, dan dalam hal ini peneliti melihat langsung pada percakapan tersebut. (3) Teknik catat, Teknik catat ini digunakan untuk mencatat data atau hasil dari sebuah percakapan mahasiswa surabaya.

Tahapan dalam pengumpulan data ini sebagai berikut; (a) Menentukan Objek Data :Objek yang dipilih sebagai data dalam penelitian ini adalah Percakapan Mahasiswa Di Surabaya. (b) Merekam Pembicaraan : Peneliti berpartisipasi aktif dalam pembicaraan dan merekam hasil pembicaraan tersebut dengan menggunakan perekam Handphone, pembicaraan tersebut diperoleh dari percakapan mahasiswa di Surabaya lebih tepat di sebuah kafe dan taman yang mengandung Deiksis. (c) Mencatat dan Menstranskrip : Data yang berupa rekaman suara tersebut dicatat dan ditranskrip ke dalam bentuk data tulis. Hal ini dapat mempermudah dalam proses memasukkan data. (d) Pemberian Kode Data : Pemberian kode data dapat mempermudah dalam proses menganalisis data, dan pemberian kode ini dimaksudkan sebagai identitas pada setiap data seperti nama Deiksis yang dilakukan agar lebih jelas.

Teknik analisis data pada penelitian ini dilakukan dengan langkah-langkah sebagai berikut (1) Peneliti mengklasifikasikan (menggelompokkan atau menggolongkan) data penemuan deiksis yang berasal dari transkrip percakapan mahasiswa multukultural Surabaya yang didasarkan jenis deiksis dengan deiksis dari teori Levinson yakni deiksis terdiri atas deiksis persona, deiksis waktu, dan deiksis ruang atau tempat. (2) Peneliti memberikan interpretasi berupa pejelasan terkait konteks dari deiksis persona yang berasal dari transkrip percakapan mahasiswa multukultural Surabaya. Agar lebih mudah, maka peneliti mengelompokkan temuan deiksis persona berdasarkan teori deiksis yang terdiri atas persona pertama, persona kedua, dan persona ketiga, dalam bentuk tunggal dan jamak. (3) Peneliti melakukan analisis deiksis waktu pada data yang diperoleh 
dengan mengklasifikasikan konteks berdasarkan rujukan pada jam, tahun dan bulan. (4) Peneliti mengklasifikasikan yang mengandung deiksis waktu atau tempat berdasrkan dua hal yakni data yang mengandung deiksis tersebut berada dekat atau jauh dengan lokasi penutur dan mitra tutur. (5) Selanjutnya peneliti menjumlahkan penggunaan deiksis tersebut dari masing-masing bentuk deiksis yang ditemukan.

\section{HASIL DAN PEMBAHASAN}

Berdasarkan hasil penelitian, macam- macam deiksis terdiri atas deiksis persona, deiksis tempat, dan deiksis waktu. Deiksis persona terdiri atas tiga jenis yakni deiksis persona pertama, deiksis persona kedua, dan deiksis persona kedua. Deiksis persona dibagi atas deiksis persona tunggal dan deiksis persona jamak. Selanjutnya, deiksis tempat terdiri dari tiga jenis yakni deiksis tempat Lokatif dan deiksis tempat Demonstratif. Sedangkan deiksis waktu terdiri dari tiga jenis yakni deiksis waktu yang lalu, deiksis waktu yang sekarang, dan deiksis waktu yang akan datang. Hal tersebut tentu terkait dengan analisis data.

Dalam analisis data, digunakan teori dari Levinson, khususnya dalam menentukan jenis deiksis. Levinson membagi deiksis terdiri atas deiksis persona, deiksis waktu, dan deiksis tempat. Berdasarkan data-data yang telah dikumpulkan dan disajikan pada bagian ini akan memaparkan hasil temuan atau analisis data berdasarkan jumlah temuan deiksis dalam bentuk percakapan. Berikut ini akan dipaparkan beberapa data tentang deiksis persona, deiksis tempat, dan deiksis waktu. (Levinson, 1983:69).

\section{a. Deiksis Persona Pertama}

Deiksis Persona Pertama merupakan Deiksis yang menunjuk referensi penutur untuk dirinya sendiri. Berikut ini akan memaparkan beberapa data yang akan diuraikan mengenai deiksis persona pertama.

(1) Cia :"Lo Ndahyo, Dikiro aku pertemuan biasa"

Dian :"Sama aku, kenapa, hee"

Hero :"Ohh iya,"

Pada data (1) termasuk deiksis persona tunggal dengan wujud aku. Jika dikaitkan dengan teori deiksis, maka kata aku pada data (1) adalah deiksis persona pertama karena kata $a k u$ berfungsi untuk menggantikan kata ganti orang pertama yang sedang melakukan tuturan atas pembicaraan secara langsung. Kata aku pada data (1) merujuk pada orang yang berbeda. Berdasarkan konteks yang ada, tuturan terjadi di Taman Wolu Kampus Menanggal Surabaya dalam situasi santai yang berkaitan tentang pertemuan antara Cia dan Dian. Kata $a k u$ yang pertama digunakan oleh Cia dari Mentawai. Sedangkan kata $a k u$ yang kedua rujukannya pada Dian. Sebelum munculnya kata aku yang kedua yang merujuk pada Dian, nama Dian telah disebut oleh Cia $(a k u)$ dalam tuturannya terlebih dahulu.

(2) Tika :"Iku loh sek akeh"

Reni :" Aku boleh minta spidole?"

Salma :"Iya ini spidole"

Tika :"Iki balone piroan rek?"

Reni :"10ribu an" 
Berbeda pada data (1), Pada data (2) di atas merupakan deiksis persona tunggal dengan wujud $a k u$. Penggunaan kata $a k u$ pada data (2) adalah deiksis persona pertama, karena kata $a k u$ berfungsi untuk menggantikan kata ganti orang pertama yang sedang melakukan tuturan atas pembicaraan secara tidak langsung. Berdasarkan konteks yang ada, tuturan ini terjadi di sebuah kost yang berada di Surabaya dalam situasi santai. Tuturan kata $a k u$ berkaitan tentang peminjaman spidol dan menanyakan harga balon. Kata $a k u$ dalam percakapan ini digunakan oleh Reni. Dalam kata $a k u$ merujuk pada Salma.

(3) Dian :"Rengginang yang ada ikannya"

Rido :"Lorjuk"

Dian :"He e, lorjuk nitip po'o mas, aku kepengen mas"

Rido :"Ngidam ta"

Berbeda lagi pada data (2), pada data (3) di atas termasuk deiksis persona dalam bentuk tunggal dengan wujud $a k u$. Kata $a k u$ pada data (3) di atas merujuk pada Dian yang ingin menitip makanan lorjuk. Berdasarkan konteks yang ada, tuturan ini terjadi di Taman Wolu Kampus Menanggal Surabaya dalam situasi santai Sebelum munculnya kalimat pada data (3), Dian bertanya kepada Rido tentang rengginang yang ada ikannya yang bisa disebut dengan Lorjuk. Jika di kaitkan dengan teori deiksis, maka kata aku memilik rujukan pada Dian.

\section{b. Deiksis Persona Kedua}

Deiksis Persona Kedua adalah penggunaan kata ganti orang kedua untuk menunjuk kepada satu atau lebih lawan tuturannya. Berikut ini akan di paparkan beberapa data yang akan diuraikan mengenai deiksis persona kedua.

(4) Rido :"Kamu petis itu dari mana, dari madura aja iya"

Dian :"Kalau petis dari madura itu beda bang, sebenarnya dari jawa itu pakai udang. Tapi Kalau yang dari madura itu kan Cuma ikan"

Rido :"Jadi udang itu dari jawa"

Pada data (4) di atas terdapat kata ganti persona kamu. Berdasarkan konteks yang ada, tuturan tersebut dituturkan oleh Rido di sebuah Taman Wolu Kampus Menanggal Surabaya dalam situasi gembira. Kata kamu merupakan deiksis persona kedua dalam bentuk tunggal. Pada data (4) di atas merujuk pada penutur dan mitra tutur. Pada data (4) di atas jika dikaitkan dengan teori deiksis, maka kata kamu bermaksud merujuk pada Dian. Rujukan dapat diketahui karena tuturan di atas dilakukan oleh Hero.

(5) Dian :"Ini Semua dosen pak irfan, mom endang"

Hero :"Mangkanya jangan-jangan, dibatasi karena saudara anda itu dibatasi karena sesuatu aja"

Cia :"Bisa aja aliti cak” (DPKED-2)

Selanjutnya pada data (2) di atas merupakan deiksis persona kedua dengan wujud anda. Penggunaan kata anda jika dikaitkan dengan teori deiksis, maka 
berfungsi untuk menggantikan kata ganti orang kedua yang sedang melakukan tuturan atas pembicaraan. Berdasarkan konteks yang ada, tuturan terjadi di Taman Wolu Kampus Menanggal Surabaya dalam situasi gembira yang berkaitan tentang pembahasan dosen. Pada data (2) di atas kata anda merujuk pada Cia dan Dian. Rujukan dapat diketahui karena tuturan di atas dilakukan oleh Hero.

(6) Nurul :"Kalau semester ini liburan aku enggak mau"

Irene :"Mana ada, memangnya kalian yakin ada ke ringganan ke longgaran untuk bisa bersenang-senang semester ini"

Naji'atu :“Ada, semester delapan”

Pada data (3) di atas memiliki wujud deiksis berupa kalian. Penggunaan kata kalian merupakan deiksis persona kedua dalam bentuk jamak yang memiliki rujukan pada lebih dari satu persona atau gabungan antara persona pertama dengan persona kedua. Kata kalian digunakan untuk mengganti orang yang disebut dalam percakapan jumlahnya lebih dari satu, tetapi penutur tidak termasuk di dalamnya. Pada data (3) merujuk pada penutur dan mitra tutur. Berdasarkan konteks yang ada, tuturan tersebut merujuk di sebuah kost yang berada di Surabaya dalam situasi santai. Kata kalian merujuk pada Nurul dan Naji'atul. Rujukan dapat diketahui karena tuturan di atas dilakukan oleh Irene.

\section{c. Deiksis Persona Ketiga}

Deiksis Persona Ketiga merupakan referensi yang menunjuk selain diri penutur maupun lawan tuturannya. Berikut ini akan di paparkan beberapa data yang akan diuraikan mengenai deiksis persona ketiga.

(7) Deta :"He'em dan anaknya tuh iya itu kan"

Bagas :"Lo emang itu dia organisasine tertutup opo terbuka"

Nida :"Iku gak sih, aku ero jeneng e sopo bunor gak sih"

Berbeda dengan data (1), pada data (1) di atas memiliki deiksis persona ketiga dengan wujud dia. Pada data (1) disebut deiksis persona ketiga karena orang yang tidak hadir dalam tempat terjadinya pembicaraan tetapi menjadi bahan pembicaraan. Tetapi dalam konteks ini kedua pembicaraan tersebut tidak dalam lokasi yang sama. Jika kedua penutur serta bahan yang dijadikan pembicaraan tidak berada dalam tempat yang sama. Berdasarkan konteks yang ada, tuturan ini terjadi di ini terjadi di Kantin UNAIR kampus B Surabaya dalam situasi santai. Kata dia merujuk pada Teman Deta dan Nida. Rujukan dapat diketahui karena tuturan di atas dilakukan oleh Bagas.

(8) Nursiah :"Soalnya kemarin kan apa?”

Kak Sherly :"Kalau missal kita transit dari"

Kak Vena :"Kalau yang untuk Makassar-Bali sudah full masih ada penumpang ya terpaksa, ya penumpang yang lain bias ikut pesawat transit yang ke Labuan Bajo ke Bali

Nursiah :"Em... soalnya kemarin” 
Kak Sherly :"Tapi itu rasanya itu keliling. Karena Makassar itu berada sebelah ini nya Flores. Berarti dia harus kesana baru kesini lagi".

Nursiah : :Oh mangkanya, soalnya kemarin itu ada kakak dari”

Berikutnya pada data (2) di atas terdapat kata ganti oorang ketiga dengan wujud dia. Jika dikaitkan dengan teori deiksis, maka kata dia rujukannya pada persona atau seseorang yang sedang dibicarakan dalam peristiwa tindak tutur tetapi tidak ikut secara aktif dalam percakapan dan sedang berada jauh dari lokasi. Penggunaan kata dia pada data (2) merujuk pada seseorang yang bernama Nursiah. Rujukan dapat diketahui karena tuturan di atas dilakukan oleh Kak Sherly. Lokasi terjadinya pembicaraan dengan bahan yang dijadikan pembicaraan berada ditempat yang sama. Berdasarkan konteks yang ada, tuturan ini terjadi di sebuah kost Nursiah yang berada di kota Surabaya dalam situasi santai.

(9) Lifah :"Aku gak ngerti”

Depi :"Ini masalahnya ada satu anak ji, datang kan udah nyampai depan itu tempat-tempat berkumpul"

Vina :"Kebetulan"

Depi :"Saya mau balik dulu, kenapa? Temen saya ketinggalan. Mereka sendiri lo, dia katanya mau ngajak ngobrol disana, siapa anjir..."

Pada data (3) di atas terdapat deiksis persona berupa kata mereka. Penggunaan kata mereka pada data di atas digunakan penutur sebagai referensi terhadap orang lain dalam bentuk jamak. Pada percakapan yang dituturkan oleh Depi di atas kata ganti persona mereka. Berdasarkan konteks yang ada, tuturan ini terjadi di Kantin UNAIR kampus B Surabaya dalam situasi santai. Oleh karena itu kata mereka dapat di kategorikan deiksis persona. Kata mereka merujuk pada Depi. Rujukan dapat diketahui karena tuturan di atas dilakukan oleh Depi.

\section{d. Deiksis Waktu Yang Akan Datang}

Bentuk deiksis waktu (mendatang) ialah merujuk pada waktu setelah tuturan terjadi. Berikut ini akan memaparkan beberapa data yang akan diuraikan mengenai deiksis waktu yang Akan Datang.

(1) Wulan :"Berapa sih tiketnya"

Irene :"Paling murah tiga juta. Padahal tahun kemarin paling mahal tiga juta. Murah lagi 1 koma 9 juta"

Wulan :"1 koma sembilan. Aku pengen keliling dunia. Hahaha........."

Berikutnya pada data (1) di atas merupakan deiksis persona waktu yang akan datang dengan wujud kemaren. Tuturan tersebut membahas tentang naiknya tiket pesawat. Berdasarkan tuturan di atas dalam situasi bahagia, yang terjadi di sebuah kantin Ngagel kampus PGRI Adi Buana Surabaya. Kata kemaren merujuk pada hari sebelum dituturkannya ujaran atau kalimat yang sedang berlangsung. Rujukan dapat diketahui karena tuturan di atas dilakukan oleh Irene. Penggunaan kata kemaren merupakan deiksis waktu yang bersifat bebas tetapi digunakan dalam waktu yang dekat dengan peristiwa terjadinya tuturan. 
(2) Kevin :"Kamu dijajahi sama orang lain"

Rendi :"Enggak bukan gitu. Masalahnya dulu enggak tahu kenapa anakanak takut sama aku waktu SMA. Enggak tahu kenapa!"

Kevin :"Takut sama kau. Hahaha.... kamu orang pulau ta karate"

Rendi :"Nggak soalnya kan emang kayak berantem gimana gitu"

Pada data (2) di atas merupakan deiksis waktu rujukan Tahun karena terdapat wujud $d u l u$. Penggunaan kata $d u l u$ merupakan deiksis waktu rujukan tahun karena rujukannya pada waktu yang merujuk pada tahun. Kata dulu pada data (2) menunjukkan bahwa waktu yang sudah terjadi pada waktu sangat lama sebelum kalimat atau ujaran di tuliskan atau dituturkan oleh penutur. Rujukan dapat diketahui karena tuturan di atas dilakukan oleh Rendi. Berdasarkan konteks yang ada, tuturan tersebut dalam keadaan senang yang berada di Kantin UNAIR kampus B Surabaya dalam situasi santai

(3) Endah :"Kok sepi ngene se ya..”

Nursiah :"Aku lo selalu kalau bimbingan pasti nunggu besoknya baru aku ngerjain. Tadi pas tak edit terakhir tadi pagi."

Chandri :"Aku itu kalau magang senang aja.."

Naji'atul :"Kenapa .."

Chandri :"Senang saja. Pokoknya aku kalau magang itu senang aja. Tidak ada rasa beban.."

Pada data (3) di atas memiliki wujud deiksis berupa kata besuk. Penggunaan kata besuk merupakan deiksis waktu yang merujuk pada hari. Jika dikaitkan dengan teori deiksis, maka deiksis waktu menunjuk pada waktu yang mendekati tuturan ataupun waktu yang menjauh tuturan. Kutipan pada data (3) di atas dapat diketahui bahwa kata besuk merupakan deiksis waktu yang mengarah menjauh dari tuturan yang sedang berlangsung. Rujukan dapat diketahui karena tuturan di sampaikan oleh seseorang yang bernama Nursiah. Jadi kata besuk pada data (3) merujuk pada hari setelah dituturkannya kutipan pada data di atas. Berdasarkan konteks yang ada, tuturan tersebut berada di Adi Buana kampus 1 gedung A Surabaya dalam situasi gembira.

\section{e. Deiksis Waktu Yang Lalu}

Bentuk deiksis waktu yang telah lalu ialah merujuk pada waktu setelah saat tuturan terjadi. Berikut ini akan memaparkan beberapa data yang akan diuraikan mengenai deiksis waktu yang telah lalu.

(1) Rido :"Temen, ngidam ae"

Dian :"Ngidam apa coba,engggak aku lagi pengen ae."

Rido :"Temen, ngidam ae"

Dian :"Iya, aku lagi lagi pengen ae. Soalnya kan udah beberapa tahun gitu lagi pernah nyobain, ketagihan wenak sampai sekarang aku kok 
udah lama gak di bawain. Buat apa petis, aku udah pernah makan petis yang madura disana. Aku kenyang kok"

Pada data (1) memiliki kata deiksis berupa beberapa tahun. Penggunaan kata beberapa tahun ini merupakan deiksis waktu yang memiliki rujukan pada tahun dengan rujukan diungkapkan secara langsung oleh penutur. Kata beberapa tahun pada data di atas rujukannya pada tahun karena merujuk pada waktu lampau sebelum dituturkannya ujaran atau kalimat tersebut. Berdasarkan konteks yang ada, tuturan terjadi di Taman Wolu Kampus Menanggal Surabaya dalam situasi gembira. Oleh karena itu kata keterangan beberapa tahun pada data (1) di atas dapat dikategorikan ke dalam jenis deiksis waktu. Tuturan ini disampaikan oleh Dian.

(2) Nurul :"Kok beda iya"

Irene :"Beda apa"

Nurul :"Kok di storynya nada itu kayak sumpek gitu, ini kok rapi iya"

Irene :"Mungkin bulan lalu masih berantakan"

Pada data (2) di atas merupakan deiksis waktu yag merujuk pada bulan karena terdapat wujud bulan lalu. Jika dikaitakan dengan teori deiksis, maka kata bulan lalu merujuk pada tahun yang jauh dengan munculnya tuturan yakni rujukannya adalah bulan. Tuturan tersebut berkaitan tentang pembahasan kamar kost yang ditempati oleh Irene. Berdasarkan konteks yang ada, tuturan ini terjadi di sebuah kost Irene yang berada di Surabaya dalam situasi santai. Tuturan ini disampaikan oleh Irene.

(3) Nursiah :"Loh itu.. iya"

Kak vena :"Selamat malam. Malam kak. Paket saya, saya sampainya kapan? Soalnya udah, udah berapa hari?"

Nursia :"Sudah tiga hari kok"

Kak vena :"Sudah tiga hari setelah pemesanan sudah sampe. Eh biasanya ini ada bilang begini apa barang siap dikirim"

Pada data (3) di atas merupakan deiksis persona waktu yang lalu dengan wujud beberapa hari (yang lalu). Tuturan tersebut berkaitan tentang pengiriman barang. Kata beberapa hari (yang lalu) merujuk pada hari dengan rujuk di ungkapkan secara langsung oleh penutur. Berdasarkan konteks yang ada, tuturan ini terjadi di sebuah kost Nursiah yang berada di Surabaya dalam situasi santai. Kata beberapa hari pada data di atas rujukannya pada hari karena merujuk pada waktu lampau sebelum dituturkannya ujaran atau kalimat tersebut. Oleh karena itu kata beberapa hari (yang lalu) disebut jenis deiksis waktu. Tuturan tersebut disampaikan oleh Kak Vena.

\section{f. Deiksis Waktu Yang Akan Datang}

Bentuk deiksis waktu (yang akan datang) ialah merujuk pada waktu saat terjadinya tuturan. Berikut ini akan memaparkan beberapa data yang akan diuraikan mengenai deiksis waktu yang akan datang.

(1) Irene :"Lo dosenmu itu sudah jelas.. ini masih awal”. 


\section{Nurul :"Kan dosenmu sudah pasti" \\ Irene :"Iya tapi aku belom apa-apa, kasihani dirimu. Cuman kamu sendiri yang seperti itu dipindah-pindah..Memang minggu- minggu ini masih belum ada kepastian dengan bimbingan"}

Pada data (1) di atas merupakan deiksis waktu dengan wujud minggu ini. Tuturan ini disampaikan oleh Irene. Penggunaan kata minggu ini merujuk pada Hari yang dimana Irene yang sedang bimbingan. Berdasarkan konteks yang ada, tuturan ini terjadi di sebuah kost Irene yang berada di Surabaya dalam situasi santai. Tuturan tersebut berkaitan tentang pengiriman barang. Kata minggu ini merujuk pada hari dengan rujuk di ungkapkan secara langsung oleh penutur. Oleh karena itu kata minggu ini disebut pada deiksis waktu. Tuturan tersebut disampaikan oleh Irene.

(2) Wulan :"Haa seminggu."

Irene :"Jadi satu-satunya yang paling enak itu naik pesawat. Tapi sekarang PP mahal"

Wulan :"2020 naik"

Irene : :Aku yakin tahun ini, tahun 2020 turun, karena presidennya sudah ada. Karena presiden belum apa-apa. Jadi gak bisa ngelarang”

Pada data (2) di atas merupakan deiksis waktu dengan wujud tahun ini. Kata tahun ini disampaikan pada Irene. Tuturan pada data (2) di atas bermaksud tentang pembahasan tiket pesawat dan presiden tahun 2020. Berdasarkan tuturan di atas dalam situasi bahagia, yang terjadi di sebuah kantin Ngagel kampus PGRI Adi Buana Surabaya dalam situasi bahagia. Penggunaan kata tahun ini merujuk pada hari dengan rujuk di ungkapkan secara langsung oleh penutur. Oleh karena itu kata tahun ini disebut pada deiksis waktu.

(3) Bayu :"Ni semua satu kelompok bimbingan?"

Sodiq :"Iyo mas hahaha".

Fredo :"Iya betul bay".

Bayu :"Hari ini bimbingan bang?"

Edo :"Hah! Apa!"

Pada data (3) di atas memiliki deiksis persona waktu dengan wujud hari ini. Kata hari ini merujuk pada Sodiq dan Edo. Rujukan dapat diketahui karena tuturan di atas dilakukan oleh Bayu. Penggunaan kata hari ini pada data di atas rujukannya pada hari karena merujuk pada waktu yang akan datang setelah dituturkannya ujaran atau kalimat tersebut. Berdasarkan konteks yang ada, tuturan tersebut berada di Kampus UNTAG Surabaya dalam situasi santai. Oleh karena itu kata hari ini disebut jenis deiksis waktu.

\section{g. Deiksis Tempat Lokatif}

Deiksis tempat lokatif merupakan Lokasi sebuah objek yang ditunjukan oleh sebuah kata deiksis ditentukan berdasarkan lokasi tempat si penutur yang mengujarkan kata deiksis tersebut. Berikut ini akan memaparkan beberapa data yang akan diuraikan mengenai deiksis tempat lokatif. 
(1) Kevin :"Tapi disana ada yang nyontohnyontoh enggak"

Rendi :"Iya nyontoh ada, tapi paling anak yang parah banget bandelnya."

Kevin :"Aku bersyukur rek, dulu SMA ku beli joki, kamu beli joki enggak"

Berikutnya pada data (1) di atas terdapat kata ganti keterangan tempat $d i$ sana. Kata di sana digunakan sebagai pengganti keterangan tempat. Kata di sana rujukannya adalah tempat yang berada jauh dari penutur. Penggunaan kata di sana pada data (1) di atas merujuk pada sebuah Sekolah Menengah Atas yang dituturkan oleh Kevin yang merujuk pada Rendi. Oleh karena itu dapat diketahui dengan jelas bahwa antara penutur dan mitra tutur sama-sama mengetahui lokasi kata di sana. Berdasarkan konteks yang ada, tuturan tersebut dalam keadaan senang yang berada di Kantin UNAIR kampus B Surabaya.

(2) Irene :"Ada villa enggak sih disana”

Wulan :"Ada kok"

Irene :"Aku takut ke tempat-tempat gitu. Ayok lima juta itu kita kesana"

Naji'atul :"Itu masih nambahin banyak lo untuk kesana"

Wulan :"Belum makannya"

Pada data (2) di atas memiliki deiksis tempat yang berupa kata ke sana. Penggunaan kata ke sana digunakan untuk merujuk kepada kepada lokasi yang berada jauh dengan penutur ketika melakukan tindak tutur. Kutipan di atas dituturkan oleh Irene. Rujukan dapat diketahui karena tuturan di atas dilakukan oleh Irene. Berdasarkan tuturan di atas dalam situasi bahagia, yang terjadi di sebuah kantin Ngagel kampus PGRI Adi Buana Surabaya. Kata ganti keterangan tempat ke sana merujuk pada villa. Kata ganti keterangan tempat ke sana digunakan oleh Irene untuk menunjukkan lokasi tempat tujuan yang akan mendatangi tempattempat villa. Rujukan mengenai di mana posisi kata ke sana dapat diketahui dari kalimat Irene sebelumnya yang menyebutkan Villa. Kata ini digunakan untuk memperjelas lokasi yang ditunjuk oleh kata ke sana.

(3) Irene :"5 tahun, ini tahun ketiga"

Naji'atul :"Kenapa, bedanya disini sama disana itu apa"

Irene $\quad$ :Disini itu enak sih. Apa-apa gitu enak, di papua sana serba mahal iya makanannya".

Berikutnya pada data (3) di atas memiliki deiksis tempat berupa kata di sini. Kata di sini merupakan kata keterangan tempat. Penggunaan kata di sini digunakan untuk merujuk kepada lokasi yang berada dekat dengan penutur ketika mengeluarkan tuturan. Berdasarkan konteks yang ada, tuturan ini terjadi di sebuah kost Irene yang berada di Surabaya dalam situasi santai. Pada percakapan di atas dituturkan oleh Irene, kata ganti keterangan tempat di sini menunjukkan lokasi penutur dan pendengar. 
(4) Masduki :"Kalau kamu?"

Bayu :"Kalau Aku Fakultas Keguruan Ilmu Pendidikan, Pendidikan Bahasa Indonesia."

Masduki :"Loh.. di UNTAG adanya Sastra Jepang dan Inggris. Kamu dari kampus mana?"

Bayu :"Dari kampus ADI BUANA."

Masduki :"Oh... ADI BUANA. Sampai kesini ngapain?"

Bayu : "Ngopi aja mas, sambil cari teman baru."

Pada data (4) di atas terdapat deiksis tempat berupa kata ke sini. Penggunaan kata ke sini merupakan kata ganti keterangan tempat yang lokasinya berada dekat dengan penutur dan pendengar. Kata ke sini menerangkan sesuatu yang bergerak mendekati lokasi penutur. Pada data di atas diketahui bahwa penutur mendekati lokasi yang di ganti dengan kata ke sini. Kata ke sini di atas rujukannya ialah mencari teman baru sambil minum kopi. Berdasarkan konteks yang ada, tuturan tersebut berada di Kampus UNTAG Surabaya dalam situasi santai. Pada data (4) di atas kata ke sini merujuk pada Lokasi. Rujukan dapat diketahui karena tuturan di atas dilakukan oleh Masduki.

\section{h. Deiksis Tempat Demonstratif}

Deiksis tempat demonstratif merupakan Sistem pronomina demonstratif dalam bahasa Indonesia tidak paralel dengan kata penunjuk tempat, hanya dikenal adanya dua perbedaan pronominal demonstratif ini dan demonstratif itu.

(1) Hero : "Kalau kawan-kawan gimana iya"

Dian :Kalau itu bukan primer ngunu iku, temen-temen kan sekunder,biyen kan karo primer dan sekunder"

Hero :"Nah mangkanya, kalau dari budaya primer dan sekunder, itu mangkannya lebih ke sunda gitu"

Pada data (1) di atas memiliki deiksis tempat berupa kata itu. Penggunaan kata itu disebut deiksis tempat karena rujukannya sudah dijelaskan sebelum kata deiksis muncul. Pada data di atas terdapat nama tempat yang muncul tetapi wujud itu pada data (1) merujuk pada Sunda. Rujukan pada data di atas dapat diketahui karena kata Sunda sebelumnya muncul dan disampaikan oleh Dian yang menceritakan tentang Kebudayaan Sunda. Berdasarkan konteks yang ada, tuturan terjadi di Taman Wolu Kampus Menanggal Surabaya dalam situasi santai.

(2) Rido :"Mau ngundang"

Dian :"Bukan mas, yang seminar des start yang dari malang itu lo"

Rido :"Katanya enggak, enggak wajib"

Berbeda pada data (1), pada data (2) di atas merupakan deiksis tempat dengan wujud itu. Penggunaan kata itu merujuk pada tempat yang jauh dengan penutur atau mitra tutur. Tuturan ini berkaitan tentang pembahasan seminar dari Malang. Berdasarkan konteks yang ada, tuturan terjadi di Taman Wolu Kampus 
Menanggal Surabaya dalam situasi santai. Oleh karena itu kata itu disebut deiksis tempat demonstratif. Berbeda lagi dengan data (81), pada data (2) di atas kata itu merujuk pada Ridho. Rujukan dapat diketahui karena tuturan di atas dilakukan oleh Dian.

(3) Nursiah :"Loh kan 15"

Kak Vena :"He padahal tanggal 15 ini lho Bratang Gedenya. Tunggu balasan. Bias cek disini kak. Yaiyalah. Ini lho langsung dikirim hari itu juga kamu pesan tanggal 13 kan?"

Nursiah :"Hem..."

Pada data (3) di atas memiliki deiksis tempat dengan wujud ini. Berdasarkan konteks yang ada, tuturan ini terjadi di sebuah kost yang berada di Surabaya dalam situasi santai. Penggunaan kata ini disebut deiksis tempat karena rujukannya sudah dijelaskan atau disebutkan sebelum kata deiksis muncul. Kata ini disebut deiksis tempat karena rujukannya sudah dijelaskan atau disebutkan sebelum kata deiksis muncul. Pada data ini merujuk pada Kota Bratang Gede. Rujukan data (3) dapat diketahui karena "Bratang Gede" sebelumnya muncul dan disampaikan oleh Kak Vena. Kata ini merujuk pada lokasi jauh dengan penutur maupun mitra tutur. Oleh karena itu kata ini disebut dengan deiksis tempat demonstratif.

(4) Ainun :"Ini suratnya sendiri-sendiri?"

Tika :"Heem. Andaikan yo nun kamu itu tak kasih tiga pilihan habis lulus kuliah kamu sing pertama mau lanjut S2, yang kedua apa kamu ngajar terus nikah, yang ketiga apakah kamu mau ke Pare satu tahun?"

Ainun :"Ke Pare satu tahun?"

Tika :"Heem belajar bahasa Inggris" (DTDEM-4)

Selanjutnya pada data (4) di atas merupakan deiksis tempat dengan wujud ini. Berdasarkan konteks yang ada, tuturan ini terjadi di sebuah kost yang berada di Surabaya dalam situasi santai. Pada data (4) diatas kata ini merujuk pada lokasi jauh dengan penutur maupun mitra tutur. Penggunaan kata ini disebut deiksis tempat karena rujukannya sudah dijelaskan atau disebutkan sebelum kata deiksis muncul. Pada data ini merujuk pada Kota Pare. Berbeda lagi dengan data (3), pada data (4) di atas kata ini merujuk pada Tika. Rujukan dapat diketahui karena tuturan di atas dilakukan oleh Ainun.

\section{PEMBAHASAN}

Dari hasil penelitian penggunaan deiksis dalam percakapan Deiksis dalam interaksi verbal mahasiswa di Surabaya dapat diuraikan suatu pembahasan yakni penelitian memaparkan data-data hasil penelitian yang keseluruan diambil dari analisis data. Hal ini terkait dengan interaksi verbal mahasiswa di Surabaya. Adapun jenis deiksis dalam percakapan mahasiswa di Surabaya menurut Levinson yaitu: deiksis persona, deiksis waktu, dan deiksis tempat. Di dalam deiksis persona di bagi menjadi deiksis persona pertama, deiksis persona kedua, dan deiksis persona ketiga. Deiksis persona terdiri dari Deiksis persona dibagi menjadi dua yaitu pertama dan tunggal. 
Dari jenis deiksis yang dinyatakan oleh Levinson yang paling banyak digunakan dalam percakapan mahasiswa di Surabaya yang meliputi deiksis persona sebanyak 30 deiksis, deiksis waktu sebanyak 16 deiksis, dan deiksis tempat sebanyak 20 deiksis.

Dari tiga jenis deiksis yang ditemukan peneliti, terdapat deiksis persona yang paling banyak digunakan dalam kumpulan percakapan Mahasiswa di Surabaya. Deiksis persona yang dimaksud peneliti termasuk dalam teori Levinson, deiksis persona menurut Levinson memiliki persamaan dengan deiksis persona pertama, persona kedua dan persona ketiga. Hal ini terjadi pada percakapan mahasiswa di Surabaya. Deiksis persona berhubungan dengan pemahaman mengenai peserta pertuturan dalam situasi pertuturan di mana tuturan tersebut dibuat. Sebagaimana dengan deiksis persona pertama, persona kedua, dan persona ketiga yang mengandung unsur perbedaan.

Dalam pembahasan ini peneliti telah memfokuskan pada deiksis percakapan mahasiswa di Surabaya. Hal ini sesuai dengan teori Levinson yang menyatakan bahwa deiksis ada 5 jenis, tetapi peneliti mengambil 3 jenis deiksis, dan tiga jenis deiksis terdapat dalam percakapan mahasiswa di Surabaya yang telah di analisis.

Adapun temuan penelitian terdahulu yang relevan yaitu jurnal karya Md. Aminudin A. (2016) yang berjudul Deiksis dalam Novel Tembang Ilalang. Permasalahannya yakni terletak pada deiksis yang ditemukan. Persamaan dari penelitian tersebut dengan penelitian yang dilakukan peneliti yaitu sama-sama mengkaji tentang tiga jenis deiksis. Perbedaannya terletak pada objek penelitiannya Md. Aminudin A menggunakan objek Novel karena novel merupakan bentuk prosa rekaan yang lebih pendek daripada roman atau yang disebut dengan fiksi sedangkan peneliti menggunakan objek percakapan mahasiswa di Surabaya.

Temuan penelitian terdahulu yang relevan berikutnya yaitu jurnal karya Tologana (2016) yang berjudul Deiksis Dalam Novel "Assalamualaikum Beijing" Karya Asma Nadia. Permasalahannya yakni pada penelitian Tologana terdapat lima jenis deiksis diantaranya yaitu deiksis persona, deiksis waktu, deiksis tempat, deiksis wacana, dan deiksis sosial pada novel yang dianalisis. Persamaan penelitian yang dilakukan yaitu sama-sama mengkaji tentang deiksis. Perbedaannya terletak pada objek yang dikaji. Tologana mengkaji tentang novel, sedangkan peneliti menggunakan objek percakapan Mahasiswa di Surabaya.

Temuan penelitian terdahulu yang selanjutnya yaitu jurnal (2015) karya Darsita yang berjudul "Deiksis" dalam Kumpulan Cerpen Al-Kabuus Tinjauan Sosiopragmatik. Hal tersebut memiliki kemiripan dengan penelitian sebelumnya bahwa permasalahan yang terjadi terletak pada jenis deiksis yang ditemukan. Persamaan penelitian Darsita dengan peneliti yaitu sama-sama mengkaji tentang deiksis. Penelitian yang dilakukan Darsita menggunakan objek cerpen karena cerpen merupakan kumpulan dari cerita pendek, sedangkan peneliti menggunakan percakapan mahasiswa di Surabaya.

Berbeda dengan penelitian percakapan Mahasiswa di Surabaya yang berjumlah tiga jenis deiksis. Dari masing-masing penelitian yang terdahulu di atas, tentu memiliki ciri khas dari objek yang diteliti. Pertama penelitian dari Md. Aminudin ditemukan tiga jenis deiksis dalam novel yang dikaji. Kedua, penelitian dari Walset Tologana ditemukan lima jenis deiksis dalam novel yang dikaji. Ketiga, penelitian dari Darsita ditemukan lima jenis deiksis dalam cerpen yang dikaji. 


\section{SIMPULAN}

Berdasarkan hasil penelitian dapat disimpulkan bahwa bagaimanakah penggunaan deiksis dalam Percakapan Mahasiswa di Surabaya. Deiksis yang terdapat dalam Transkrip Percakapan Mahasiswa di Surabaya meliputi deiksis persona (aku, saya, kita, kamu, anda, beliau, dia, mereka, kalian), deiksis waktu (dulu, kemaren, sekarang, besok, nanti, beberapa tahun, bulan lalu, beberapa hari (yang lalu), minggu ini, tahun ini, dan hari ini) dan deiksis tempat (di sini, di sana, kesana, ke sini, itu, dan ini).

Dari temuan data dapat diketahui bahwa Deiksis Persona Pertama merupakan Deiksis yang menunjuk referensi penutur untuk dirinya sendiri. Deiksis Persona Kedua adalah penggunaan kata ganti orang kedua untuk menunjuk kepada satu atau lebih lawan tuturannya. Deiksis Persona Ketiga merupakan referensi yang menunjuk selain diri penutur maupun lawan tuturannya. Deiksis tempat berhubungan dengan pemahaman lokasi atau tempat yang dipergunakan peserta pertuturan dalam situasi pertuturan. Deiksis waktu berhubungan dengan pemahaman titik ataupun rentang waktu saat tuturan dibuat (atau pada saat pesan tertulis dibuat)

Beberapa saran berikut menjadi masukan yang bermanfaat bagi pihak-pihak terkait antara lain, (1) Bagi Peneliti : Penelitian yang dilakukan terkait kajian pragmatik khususnya deiksis diharapkan dapat memanfaatkan bahasa, baik Bahasa Indonesia (dalam konteks apa saja) maupun Bahasa Daerah. Bagi penliti berikutnya diharapkan dapat meneliti deiksis lainnya seperti deiksis sosial dan deiksis wacana, sehingga dapat melengkapi penelitian yang telah dilakukan dan penelitian mengenai deiksis menjadi lebih lengkap dan mendalam. (2) Bagi Pembaca : Dapat menambah pengetahuan tentang deiksis, sehingga pembaca dapat bersosialisasi dengan baik dalam berkomunikasi. (3) Bagi Pendidik : Dapat dijadikan sebagai salah satu alternatif bahan ajar, khususnya dalam pembelajaran Bahasa Indonesia kurikulum 2013 yang berbasis teks karena penggunaan deiksis ini dapat memengaruhi keefektifan kalimat dalam pembelajaran Bahasa Indonesia keterampilan menulis.

\section{DAFTAR PUSTAKA}

Abdullah, A. (2005). Pendidikan Multikultural ; Cross-Cultural Understanding untuk Demokrasi dan Keadilan. Yogyakarta: Pilar Media.

Djajasudarma, F. (2012). Wacana Pemahaman dan Hubungan Antarsuku. Bandung: Refika Afiset.

J.Moleong, L. (1989). Metodologi Penelitian Kualitatif. Bandung: PT.Remaja Rosdakarya.

Jumanto. (2017). Pragmatik Edisi 2 Dunia Linguistik Tak Selembar Daun Kelor. Yogyakarta: Morfalingua.

Levinson, S. C. (1983 ). Pragmatics . Australia : University Of Cambridge. Nadar. (2009). Pragmatik dan penelitian pragmatik. yogyakarta: Graha Ilmu. Purwo, B. K. (1984). Deiksis dalam Bahasa Indonesia. Jakarta: Pn Balai Pustaka. Sudaryat, Y. (2009). Makna Dalam Wacana Prinsip-Prinsip Semantik dan Pragmatik. Bandung CV.Yrama Widya. 